原著

\title{
外来診療における $\mathrm{CO}_{2}$ ヒステロスコープの有用性
}

(東邦大学佐倉病院産婦人科学教室)

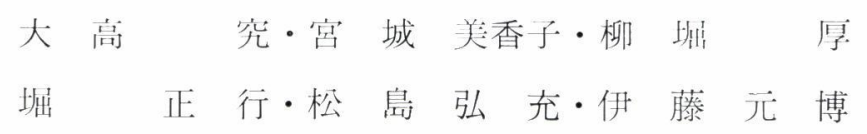

\section{緒言}

近年, 子宮鏡檢査はヒステロファイバースコー プ等の機器の開発 ${ }^{1)}$ といまって, 外来診療の一 端を担ら程に普及しつつある。しかし，液体灌流 式子宮鏡は, 光源を含め装置がやや大型で, 検者 以外に助手を必要とすることもあり, 外来での儿 ーチン检査として使用するにはよりいっそらの簡 素化が望まれる.今回，われわれは all-in-one type $\mathrm{CO}_{2}$ ヒステロスコープを外来診療に導入し, その 有用性を検討したので報告する。

\section{対象及び方法}

平成 3 年 9 月の当院開院より平成 5 年 6 月まで に不正性器出血を主訴に当科を受診し, 子宮鏡検 查を受けた 53 症例を対象とした。全例無麻酔下 で，原則として頸管拡張なしで子宮鏡検査を行 い, 症例によっては組織診を追加した。子宮鏡所 見之病理所芫を刘比するとともに検査時間につい て検討を行った。子宮鏡は西独ウルフ社製の allin-one type $\mathrm{CO}_{2}$ ヒステロスコープを使用した。本 器はスコープ, 光源部分, 子宮腔拡張用 $\mathrm{CO}_{2}$ ガス

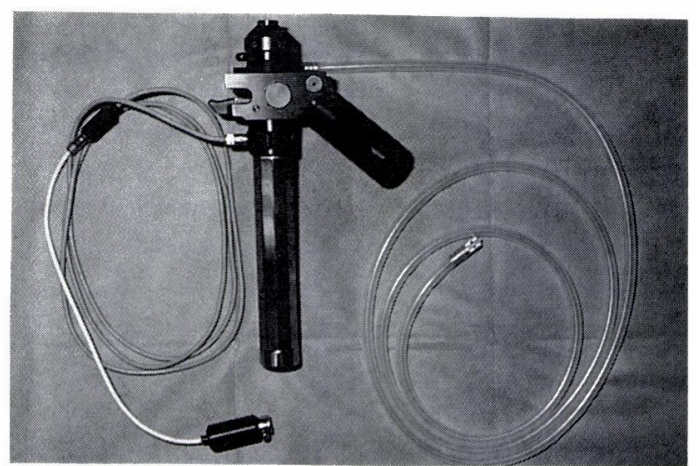

写真 1 all-in-one $\mathrm{CO}_{2}$ ヒステロスコープ

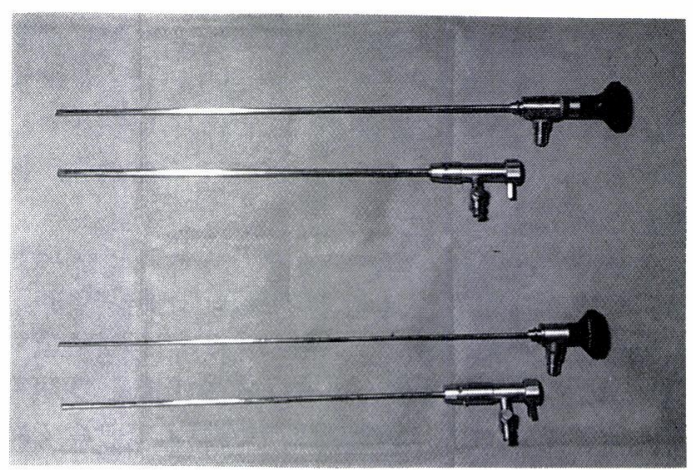

写真 2 骖断用スコープ

ボンベを一体化することが可能なコンパクトな構 造を持つ. スコープをはす゚したところを写真 1 に 小寸す中央の円筒が光源部で単 2 乾電池が 3 本入 っている. 斜めに突き出た部分に $\mathrm{CO}_{2}$ ガスのカー トリッジを装着する。 ガスの注入压は $75 \mathrm{mmHg}$, $150 \mathrm{mmHg}$ の 2 段階に調節可能である. 2 種類の 診断用スコープを写真 2 に示す. 上段のスコープ はシース径 $15 \mathrm{Fr}$, 下段は径 $10.5 \mathrm{Fr}$. である. 原 則として未産婦, 閉経後例には10.5Fr., 経産婦例 には15Fr.のスコープを使用した。

\section{結 果}

子宮鏡所見を表 1 亿示吉. その内訳は子宮内膜

表 1 子宮鏡所見

\begin{tabular}{|c|c|}
\hline 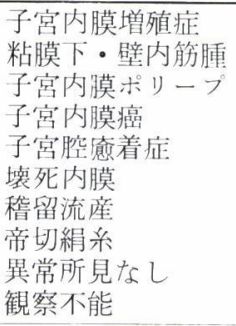 & $\begin{array}{r}21 \text { 例 } \\
10 \text { 例 } \\
7 \text { 例 } \\
5 \text { 例 } \\
1 \text { 例 } \\
1 \text { 例 } \\
1 \text { 例 } \\
1 \text { 例 } \\
3 \text { 例 } \\
3 \text { 例 }\end{array}$ \\
\hline 合 計 & 53例 \\
\hline
\end{tabular}


表 2 子宮鏡所見と病理所見の対比

\begin{tabular}{|c|c|c|c|c|}
\hline \multicolumn{2}{|l|}{ 子宮鏡所見 } & \multicolumn{2}{|c|}{ 病理所見 } & \multirow[t]{2}{*}{ 一致 率 } \\
\hline 子宮内膜増殖症 & 21 例 & $\begin{array}{l}\text { 囊胞性増殖症 } \\
\text { 腺腫性増殖症 } \\
\text { 異型増殖症 } \\
\text { 正常子宮内膜 }\end{array}$ & $\begin{array}{l}9 \text { 例 } \\
6 \text { 例 } \\
2 \text { 例 } \\
4 \text { 例 }\end{array}$ & \\
\hline 子宮内膜ポリープ & 8例 & 内膜ポリープ & 8例 & $100.0 \%(8 / 8)$ \\
\hline 子宮内膜癌 & 5例 & 腺癌 & 5例 & $100.0 \%(5 / 5)$ \\
\hline 粘膜下 - 壁内笳腫 & 3例 & 平滑筋腫 & 3例 & $100.0 \%(3 / 3)$ \\
\hline 壊死内膜 & l例 & 胎盤遺残 & 1例 & $0.0 \%(0 / 1)$ \\
\hline 稽留流産 & 1例 & 脱落膜 - 䋐毛膜 & 1例 & $100.0 \%(1 / 1)$ \\
\hline \multirow[t]{2}{*}{ 異常所見なし } & 3例 & 正常子宮内膜 & 3例 & $100.0 \%(3 / 3)$ \\
\hline & & & & $88.1 \%(37 / 42)$ \\
\hline
\end{tabular}

表 3 各種子宮鏡の比較

\begin{tabular}{|c|c|c|c|}
\hline & $\begin{array}{l}\text { 液体灌流式 } \\
\text { 硬性子宮鏡 }\end{array}$ & $\begin{array}{l}\text { ファイバー } \\
\text { スュープ }\end{array}$ & $\begin{array}{l}\text { all-in-one } \\
\mathrm{CO}_{2} \text { 子宮鏡 }\end{array}$ \\
\hline 簡便性(準備時間，人員) & $\triangle$ & $\triangle$ & (a) \\
\hline 前処置(頸管拡張，麻酔） & $\triangle$ & (a) & (a) \\
\hline 視野・視認性 & (C) & 0 & 0 \\
\hline 写真撮影 & (a) & $\bigcirc$ & $\triangle$ \\
\hline 子宮鏡下手術 & (a) & $\triangle$ & $\triangle$ \\
\hline
\end{tabular}

増殖 21 症例, 粘膜下 - 壁内筋腫 10 例, 子宮内膜 ポリープ 7 例, 子宮内膜癌 5 例, 子宮腔癒着症 1 例, 壊死内膜 1 例, 稽留流産 1 例, 帝切 絹 系 1 例, 異常所見なし 3 例で, 観察不能例が 3 例であ った. ねらい組織診，あるいは術後に摘出物の病 理学的検索を行った 42 例に括ける子宮鏡所見と 病理所見との対比を表 2 亿示す. 子宮鏡検查にて 子宮内膜増殖症と診断された 21 例は病理学的に は囊胞性増殖症 9 例, 腺腫性増殖症 6 例, 異型増 殖症 2 例で， 4 例が正常子宮内膜と診断され，両 所見の一致率は $81.0 \%(17 / 21)$ であった．子宮内 膜ポリープ, 子宮内膜癌, 粘膜下・壁内筋腫にお いては両所見は同様であり，一致率 100\%(8/8， $5 / 5 ， 3 / 3 ）$ を得た. 全体としての両検査所見の一 致率は $88.1 \%(37 / 42)$ と高率であった.

検査時間は観察のみの群で $4.48 \pm 1.52$ 分 $(\mathrm{n}=$ 25), 観察十組織診の群で $6.47 \pm 2.23$ 分 $(\mathrm{n}=17)$
と両群ともに短時間であった.

\section{考察}

不正性器出血患者や不妊症患者に対する子宮鏡

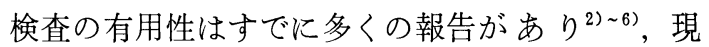
在では診断のみならず，種々の子宮鏡下手術が盛

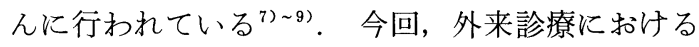
ルーチン検査としての子宮鏡検査を目的により 簡便な all-in-one $\mathrm{CO}_{2}$ ヒステロスコープを使用し てその有用性を検討し，従来から使用してきた液 体灌流式硬性子宮鏡, ヒステロファイバースコー プとの比較を行った(表 3 ).

準備時間, 検査時間については液体灌流式子宮 鏡に比べょり短時間で済め, 助手も不要で終始検 者 1 人で検查施行可能であった. 人手と時間に制 約のある外来診療には適していると思われた。

診断の正診性に関しては子宮鏡所見と病理所見 


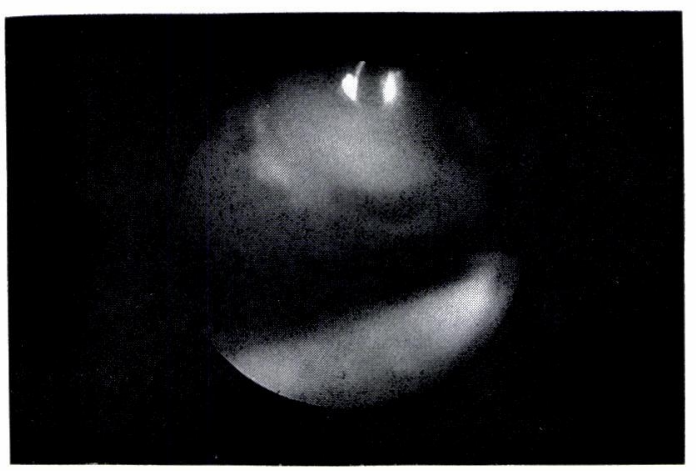

写真 3 子宮内膜增殖症

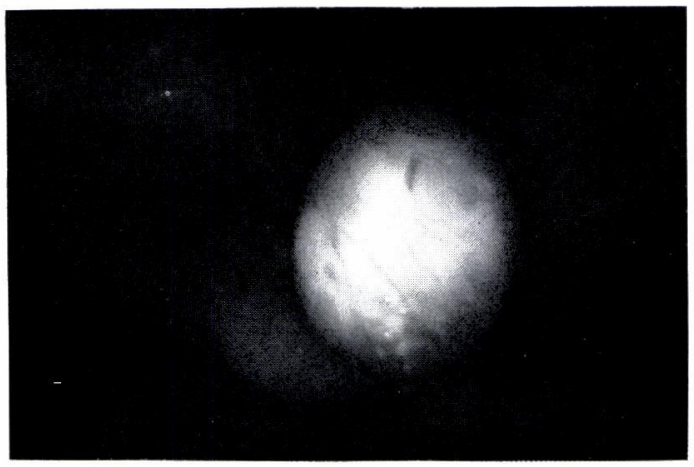

写真 4 粘膜下筋腫

の一致率が $88.1 \%$ と高率であったことからルーチ ン検査としての信頼性は十分であると言党る. $\mathrm{CO}_{2}$ ヒステロスコープは灌流液を媒介しないた め, 子宮内腔の様子がよりダイナミックに把握さ れる。例光ば, 液体灌流式の場合灌流液の注入圧 こょり内膜表面や腫瘤表面の血管像が変化してし まうことがあるが，本器では常に微細な血管構築 を観察することができる.

内膜増殖症，内膜ポリープの鑑別は難しい場合 もあるが今回の検討では内膜が子宮腔全体に肥厚 して認められた場合を内膜増殖症, 単発の大型の ポリープ状隆起を内膜ポリープと判定しだ2). 増 殖症と診断した症例は本器では液体灌流式子宮鏡 に比べ，内膜表面はより光沢が強く，ょり滑らか にとらえられた(写真 3 )。增殖症の程度の鑑別に 関して高島は異型増殖症では内膜の不透明度が著 明で異型血管を伴う場合があると述べているが 10), 今回の検討ではそこまでの把握はできなかっ た。上述のように内膜の性状や血管構築の観察に おいて本器は適していると思われ，今後症例を重 㸚て診断技術の向上に努めたい。

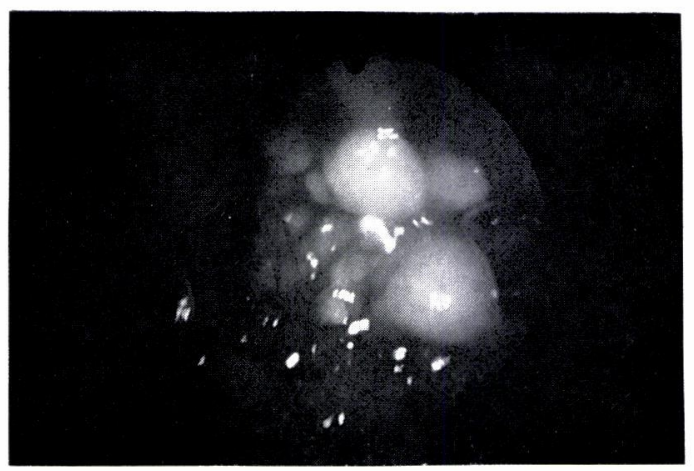

写真 5 子宮内膜癌

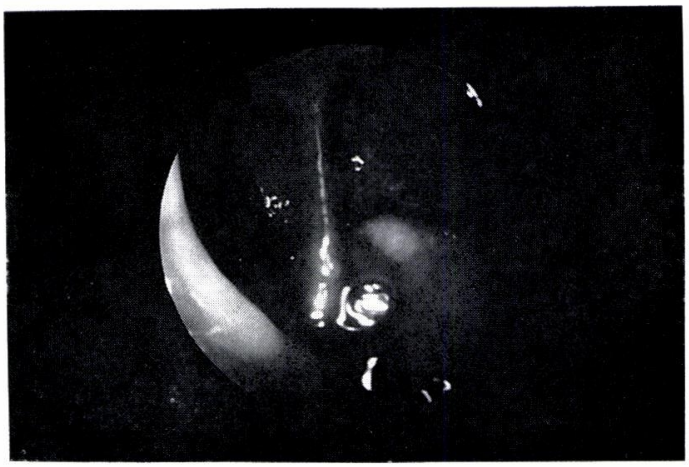

写真 6 子宮腔偲着症

粘膜下・壁内筋腫と診断した症例は表面に樹枝 状の血管を有する平滑な円形〜棈円形の隆起が認 められ 2)，その色調が強く，血管構築は液体灌流 式子宮鏡に比べ，より鮮明に把握された（写真 4 ）.

子宮内膜癌症例は全例閉経後で外子宮口は狭小 化していたが，頸管抎張なしで径 10.5Fr.のスコ ープが挿入可能であり，新たな出血を増やすこと なく, 異型血管を伴 ら内膜の乳頭状増殖 $\left.{ }^{2,}, 5,10\right)$ を 観察できた(写真 5 )。 又, スコープが極細のため 頸管〜内子宮口を損傷する危険も少なく，内膜癌 の Staging にも有効であると思われた。

1 例に子宮腔揞着が認められたが (写真 6 ), 本 症はへガールによる頸管拡張を行うと、へガール で癒着を剥離してしまう可能性も考光られる。本 器の細径のスコープは頸管拡張が不要であり, 癒 着の有無は正確に診断でき，その程度 ${ }^{4)}$ もより鮮 明に把握できると思われる。

本器の弱点はやはり子宮腔の拡張力が液体灌流 式子宮鏡に比べ劣ることと, 出血量が増元ると視 野の確保が困難になる点である。今回の検討でも 3 例が出血のため視野が得られず判定不能となっ 
た.この症例に対し 液体灌流式子宮鏡検查を追試 したところ 2 例に粘膜下筋腫が認められた。粘膜 下筋腫を有する子宮腔惕出血性であり，拡張も 困難な傾向があると思われ，このよらな埸合は液 体灌流式子宮鏡のほらが有用である。又，子宮腔 に透明な分泌物が多く貯留しており， $\mathrm{CO}_{2}$ ガスの 注入で気泡ができてしまい，観察に困難を要した 症例もあった。以上より, 確实な子宮腔の拡張と 視野の確保が不可欠な子宮鏡下手術には本器は不 向きと思われた， 又, 光源が電池式であり, 光量 に乏しく調節も効かないため, 鮮明な写真を撮る ことも難しかった.

今回検討を行った all-in-one $\mathrm{CO}_{2}$ ヒステロスコ ープはその簡便さから，外来診療で用いるには極 めて有用であると思われた。

\section{文献}

1）林 保良, 他 : ヒステロファイバー用先込め生 検鉗子の開発. 日産婦内視鏡学会誌, $8: 64$, 1992.

2）大高 究: 不妊症䛦療に扣ける子宮造影法と子 宮鏡検查併用の意義. 日不妊会誌， $36: 532$,
1991.

3) Englund, G., Ingleman-Sundberg, A. and Westin, B.: Hvsteroscopy in diagnosis and treatment of uterine bleeding Gynaecologia., $143: 217,1975$.

4) Valle, R. F. and Sciarra, J. J.: Intrauterine adhesions: Hysteroscopic diagnosis, classfication, treatment, and reproductive outcome. Am. J. Obstet. Gynecol., 158 : 1459, 1987.

5）高島英世：子宮鏡の実際. 産婦の実際，64 : 318, 1992.

6) Taylor, P. J. and Goswmy, R. K.: Hysteroscopy in infertile and habitual abortion. Human Reprod., 4 : 13, 1989.

7）小島栄吉, 他 : 子宮鏡下のレーザー治療. 臨産 婦, $42: 75,1988$.

8）林 保良, 他：レゼクトスコープによる経頸管 的切除術. 産婦の実際, 36:331, 1990.

9）森田峰人，他：レゼクトスコープによる粘膜下 筋腫切除術, 日産婦 内 視 鏡 学 会誌, $7: 31$, 1991.

10）高島英世：子宮内膜増殖症および初期内膜癌の 子宮鏡的・組織学的検索. 日 - 婦人科病理・コ ルポ誌, $10: 116,1992$. 